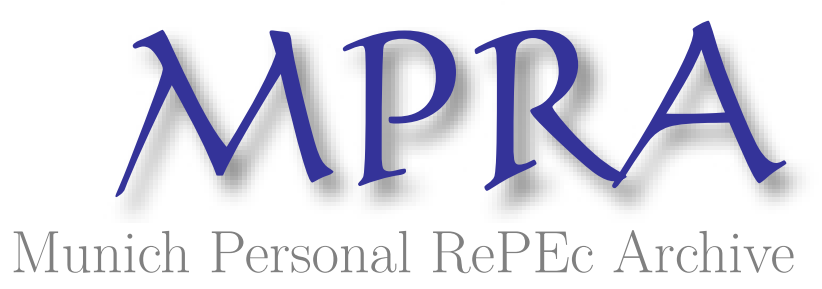

\title{
A Bibliography Search on International Migration and Remittances Literature during the period of 1971-2020: A Case of Bangladesh
}

Khan, Adnan

Migration Research Development and Society of Bangladesh (MRDSB)

2020

Online at https://mpra.ub.uni-muenchen.de/108143/

MPRA Paper No. 108143, posted 07 Jun 2021 10:20 UTC 


\title{
A Bibliography Search on International Migration and Remittances Literature during the period of 1971-2020: A Case of Bangladesh
}

\author{
Adnan Khan \\ Research Assistant \\ Migration Research Development and Society of Bangladesh (MRDSB) \\ Email: adnan@mrdsb.org \\ Sultana \\ Research Assistant \\ Migration Research Development and Society of Bangladesh (MRDSB) \\ Email: sultana@mrdsb.org
}

\begin{abstract}
With nearly 8 million of its 160 million residents living abroad, Bangladesh has one of the world's largest emigrant populations, ranking only behind India, Mexico, China, Russia, and Syria, according to estimates from the United Nations' Population Division. The increasing outward orientation of Bangladeshis after national independence in 1971 as well as the 1973 oil boom and thus an increasing need for cheap labor in the Middle East then led to a rapid growth of international labor migration from Bangladesh. In 1976, only 6,000 Bangladeshis left to work abroad. Since then, the number of both temporary expatriate workers and permanent out-migrants has increased dramatically. The main purpose of this paper is to highlight how much progress has been made in the field of international migration and remittances research on the fiftieth anniversary of Bangladesh's independence. Thus, this paper delve out all segments of international migration from Bangladesh to worldwide and remittances inflows vice versa.
\end{abstract}

Keywords: migration, expatriate, diaspora, temporary, workers, labour, remittances, literature. 


\subsection{Introduction}

As temporary workers who head overwhelmingly to the Gulf Cooperation Council (GCC) countries, Bangladeshi migrants remit much of their savings back home every month. After the Second World War, the United Kingdom faced labor shortages and therefore began to attract labor migrants of the Commonwealth states. Young men from Bangladesh, in particular from the Sylhet region, thus left for the UK, mostly settled in London, and contributed to meeting the increasing demand for cheap labor. This initiated chain migration of further workers and family members to the UK in the 1950s, 1960s and 1970s, and led to close transnational connections between Bangladesh and the UK. The states of the Gulf Cooperation Council (GCC) are the most important destinations for Bangladeshi laborers. From 1980 to 2010, the number of migrants who annually left for work in the Gulf States increased tenfold from 25,000 to more than 250,000 per year.

Bangladesh is the sixth largest origin country for international migrants in the world, with 7.8 million Bangladeshi migrants living abroad as of 2019 (UNDESA, 2019). Over 2.2 million young adults join the job market in Bangladesh each year (IOM, 2017), but the domestic labour market is unable to employ all of these individuals. Instead, many migrate internationally to secure employment and send remittances home, which are used to repay loans and to support migrant families (ibid). Remittances are an important part of the Bangladeshi economy and make up an equivalent of 5.4 per cent of the national GDP (IOM, 2018).

The majority of Bangladeshi nationals are living abroad in Saudi Arabia and India (UNDESA, 2019). In 2019, Saudi Arabia was the largest destination country for new Bangladeshi migrants (BMET, 2019). Only two per cent of migrants are considered "professional", and 48 per cent are considered low skilled (IOM, 2017; BMET, 2019). Many migrants work in construction or hazardous jobs in countries of destination (IOM, 2017; IOM, 2020). Bangladeshi women joined the international migrant labour pool in 1991, and they increased in number after 2004, when government restrictions on female migrants decreased (IOM, 2017). Women often migrate to countries in the Middle East, where they are employed as domestic workers.

Migration from Bangladesh is facilitated by either the government or by private recruitment agencies in Bangladesh; the government of Bangladesh facilitates the migration process at a lower cost than what is charged by private recruitment agencies (IOM, 2017). Intermediaries and sub-agents help to connect the Khan, A., \& Sultana. (2020). A Bibliography Search on International Migration and Remittances Literature during the period of 1971-2020: A Case of Bangladesh 
larger private recruitment agencies to migrants at local levels (IOM, 2020). Like the government, private recruitment agencies also provide skills training prior to migration (ibid).

Their contributions form a crucial lifeblood for Bangladesh, which in recent years has reduced poverty, fashioned itself into one of South Asia's economic success stories, and has been on track to exit the United Nations list of least developed countries by 2024. Yet the country, which is situated in a low-lying delta, has seen its advances hamstrung in part by persistent exposure to the adverse effects of climate change and frequent natural calamities, including cyclones and typhoons that have killed thousands over recent decades. At the same time, Bangladesh has responded to one of the largest contemporary humanitarian crises, receiving 1.1 million Rohingya who have fled neighboring Myanmar.

The COVID-19 pandemic is adding to these challenges. As the coronavirus outbreak has spread rapidly around the globe, the Bangladeshi government has struggled to combat it. The publichealth crisis has been exacerbated by the economic ripple effects resulting from the pandemic-induced difficulties faced by Bangladeshis working abroad: Large-scale job loss, salary reductions, and increase in deportations from the GCC. The migrant workers' sudden loss of income and unexpected financial precarity have profound consequences for their families and communities, with remittances that normally equal nearly one-third of Bangladesh's national budget now predicted to fall significantly.

\subsection{Methodology}

Once the scope was defined, this paper combined in-house expertiselibraries or bibliographies referred to us from members of our team-with online searches using the citation database ISI Web of Knowledge. A bibliography such as this can hardly be complete. Despite our efforts, it is obvious that there will be gaps. First, the pace of publication is such that a handful of new publications would need to be added every week. Second, our systematic search for journal articles is limited to ISI-indexed journals; many articles from other journals have also been included, but not in an exhaustive way. Third, even with the range of search terms used, we may have missed ISI-indexed articles that address return migration but use an unusual terminology. Finally, there are probably relevant books and book chapters that we simply did not discover. On the other hand, the bibliography also contains entries that may seem at odds with the scope of the bibliography as described above. These are likely to be publications sourced from the pre-existing bibliographies of the team members, 
which would not have otherwise come up in this searches. Despite these inconsistencies, it is confident that the bibliography constitute a reasonable representation of -the literature on return migrationll. The ambiguities of inclusion and exclusion nevertheless caution against bibliometric analysis.

\subsection{Findings}

The results obtained are divided into the following five categories:

\subsubsection{During the period of 1971-1980}

(Hussain 1979; ILO 1980; Islam 1980; and Mahmud \& Osmani 1980).

\subsubsection{During the period of 1981-1990}

(Ali 1981; Ali. \& Ali 1981; Boer 1981; Islam 1981; Nasiruddin 1983; Siddiqui 1983; Haque 1984; Carey \& Shukur 1985; Habib 1985; Ahmed 1986; Hossain 1986; Osmani 1986; Adams 1987; Islam et al 1987; Alam 1988; Islam 1988; Kibria 1988; McKeigue 1988; Quibria \& Thant 1988; Eade 1989; Qubria 1989, 1986; Stahl \& Habib 1989; Peach 1990; and Rahim 1990).

\subsubsection{During the period of 1991-2000}

(Islam 1991; Mahmood 1991; Osmani 1991; Salim 1992; Tomlinson 1992; Ahmed 1993; Chowdhury 1993; Faraizi 1993; Ghosh 1993; Summerfield 1993; Gardner \& Shukur 1994; King \& Knights 1994; Matin 1994; White 1994, 1992; Chowdhury
1995, 1992; Eade \& Momen 1995; Islam 1995, 1991; Khonkder 1995; Rudinick 1995; Asghar 1996; Eade et al 1996; Kotalova 1996; Knights 1996; Ahmad \& Zohora 1997; Chowdhury 1997; Firoze 1997; Gavron 1997; Islam 1997; Ahmed 1998; Chalmers 1998; Eade 1998, 1997a, 1997b, 1994, 1990; Gardner 1998, 1995, 1993a, 1993b, 1992a, 1992b, 1990; Greenhalgh et al 1998; Mahmood 1998, 1996, 1995, 1994a, 1994b, 1992, 1991; Zahid 1998; Dannecker 1999; Hadi 1999; Karim et al 1999; Kuhn 1999; Foo 1999; Mannan \& Kozlov 1999, 1997, 1995; Rahman 1999; Siddiqui et al 1999; Abrar 2000; Ahmed 2000; Achacoso 2000; Afsar et al 2000; Ali 2000; A Mu'min 2000; Flagstad 2000; Hassan 2000; Hazarika 2000; INSTRAW/IOM 2000; Ishida \& Hassan 2000; Kibria 2000, 1997; Mannan \& Krueger 2000, 1998, 1996; Rahman 2000; Shamim 2000; and Siddiqui \& Abrar 2000).

\subsubsection{During the period of 2001-2010}

(Aziz \& Rashid 2001; Blackledge 2001; Hadi 2001; Iredale \& Guo 2001; Khanum 2001; Kuhn 2001; Mannan 2001; Naved et al 2001; Rahim 2001; Siddiqui \& Abrar 2001a, 2001b; Akram 2002; Barn 2002; Blanchet 2002; Dale et al 2002; Dale et al 2002; Eade \& Garbin 2002; Ellickson 2002; Gillan 2002; Mannan \& Boucher 2002; Murshid et al 2002; Pollen 2002; Rahim 2002; Rashid 2002; Reza 2002; Titumir 2002; Kuhn \& Meneen 2003; 
Akram et al 2003; Baluja 2003; Kuddus 2003; Mahmud 2003; Miyan 2003; Phillipson 2003; Azad 2004; Abrar 2002, 2005; Akbory 2003; Kuhn 2003; Tahmina 2003; Chakraborty 2004; Datta 2004; Eade 2004; Joshi 2004; Khonkder 2004; Lawson \& Sachdev 2004; Mannan \& Krueger 2004, 2002; Menon 2004; Rahman 2004a, 2004b; Ahmed 2005; Ahmed \& Uddin 2005; Al-Azami 2005; Blanchet et al 2005; Bruyn \& Kuddus 2005; Chowdhury 2005; Dannecker 2005, 2004, 2003; Ghosh 2005; Kershen 2005; Mannan \& Kozlov 2005, 2003, 2001; Nazneen 2005; Nandy 2005; Ramachandran 2005; Ahmed 2006; Al Hasan 2006; Beaudouin 2006; Bruyn \& Wets 2006; Equal Opportunities Commission 2006; Faroque 2006; Gardner \& Ahmed 2006; Haque 2006; Hasan 2006; Lian \& Rahman 2006; Protik \& Kuhn 2006; Rahman et al 2006; Rahman et al 2006; Tackey et al 2006; Ullah \& Panday 2006; Zamir 2006; Aminuzamman 2007; Ghosh 2007, 2006; Protik \& Kuhn 2006; Sayan 2006; Zeitlyn 2006; Barua et al 2007; Higuchi 2007; Islam 2007; Islam et al 2007; Khonkder 2007; Pichler 2007; Rozario 2007; Salway 2007; Samson 2007; Subban 2007; Dale 2008; Dale \& Ahmed 2008; Haque 2008; Khan 2008; Afsar 2009, 2005, 2004, 2003, 2001; Begum \& Khondaker 2008; Buchenau 2008; Joarder \& Hasanuzzaman 2008; Khonkder 2008; Naim \& Iftikhar 2008; Rahman \& Yeoh 2008; Rahman \&
Rahman 2008; Shamshad 2008; Sikder 2008; Sultana 2008, 2005; Sultana \& Brahmmanbaria 2008; Ward \& Spacey 2008; Ahmed \& Uddin 2009; Akbar 2009; DCLG 2009; Farid et al 2009; Garbin 2009; Hasan 2009; Mannan \& Wei 2009, 2008, 2007, 2006; Moses 2009; Rahman 2009; Raihan et al 2009; Sharma \& Zaman 2009; Ahmed 2010; Alexander 2010; Chowdhury et al 2010; ILO 2010; Kibria 2010, 2009, 2008, 2007, 2006, 2005, 2004a, 2004b; Khattab et al 2010; Khonkder et al 2010; Mamun \& Nath 2010; Mehdi 2010 and Orozco 2010; Rahman 2010).

\subsubsection{During the period of 2011-2020}

(Chowdhury 2011; Deka 2011; Lie 2011; Mohsin 2011; Paul et al 2011; Paul \& Das 2011; Rahman 2011; Ahmed 2012; Barai 2012; Halder 2012; Mantoo 2012; Rao \& Hassan 2012; Stevanovic 2012; Akter et al 2013; Alam 2013; Abdullah \& Hossain 2014; Barkat \& Ahmed 2014; ADB \& ILO 2016; Ahmed 2011; Das \& Chowdhury 2011; Al-Mukit et al 2013; Bal 2013; Belanger \& Rahman 2013; Buchman 2013; Faroque et al 2013; Hassan \& Mark 2013; Islam et al 2013; Ishtiaque \& Ullah 2013; Kibria 2013, 2011a, 2011b; Khan \& Islam 2013; Khan \& Richardson 2013; Osmani \& Latif 2013; Rasinger 2013; Roshid \& Chowdhury 2013; Al-Azami 2014; Ali 2014; Barkat et al 2014a, 2014b; Bhardwaj 2014; Bose 2014; Chowdhury 2014; Chowdhury \& Khan, A., \& Sultana. (2020). A Bibliography Search on International Migration and Remittances Literature during the period of 1971-2020: A Case of Bangladesh 
Rabbi 2014; Das et al 2014; Datta \& Sarkar 2014; Ghosh 2014; Hatemi-J \& Uddin 2014; Islam 2014, 2011; Iqbal 2014; Joarder et al 2014; Mannan \& Farhana 2014a, 2014b, 2014c, 2014d, 2014e, 2014f, 2014g; Mannan et al 2014; Masuduzzaman 2014; MPC 2014; Sarkar \& Islam 2014; Sarmah \& Protim 2014; Baey \& Yeoh 2015; Biswas 2015; Chowdhury 2015; GoBILO 2015, 2014; Pradhan 2015; Mannan \& Farhana 2015a, 2015b, 2015c; Sarma 2015; Mannan \& Fredericks 2015a, 2015b; Akter 2016; Azam et al 2016; Chowdhury \& Hamid 2016; Das \& Talukdar 2016; Haider et al 2016; Hassan et 2016; IOM 2016, 2014, 2010, 2009; Islam \& Rayhan 2016; Kundu 2016; Majumder 2016; Osmani 2016a, 2016b; Rashid 2016; Regmi \& Paudel 2016; Shafiq 2016; Taguchi \& Lama 2016; Barkat \& Suhrawardy 2017; Barkat et al 2017; Hassan \& Shakur 2017; Khoda \& Shahzada 2017; Mahmud 2017, 2014; Siddiqui 2017, 2016, 2005, 2004a, 2004b, 2003a, 2003b, 2003c, 2001; Wadood \& Hossain 2017; Ahmed et al 2018; Ghelli 2018; Kumar et al 2018; Sarkar et al 2018; Mannan \& Farhana 2018; Farhana \& Mannan 2018a, 2018b; Banik \& Kumar 2019; Kumar 2019; Karim 2020; Mannan 2020, 2017a, 2017b, 2017c, 2017d, 2017e, 2016a, 2016b, 2011a, 2011b; Mannan \& Farhana 2020; Mannan et al 2020; and Rahman et al 2020).

\section{Bibliography and References}

Abdullah, A., \& Hossain, M. (2014). Brain drain: Economic and social sufferings for Bangladesh. Asian Journal of Humanity, Art and Literature, 1(1), 9-17.

Aziz, A., \& Rashid, A. (2001). Bangladeshi Migrant Workers in Malaysia's Construction Sector. Asia-Pacific Population Journal, 16(1), 322.

Abrar, C. R. (2000). On the Margin: Refugees, Migrants and Minorities. Dhaka, RMMRU.

Abrar, C. R. (2002). Cost-benefit analysis of migration. In Siddiqui Tasneem (ed.) Training manual for community leaders and activists on labour migration process. RMMRU, Dhaka.

Abrar, C. R. (2005). How Irregularities are Committed? Udbastu. 33, 4. RMMRU. Dhaka.

Achacoso, T. D. (2000). The International Labour Migration institutions of Bangladesh, India,Sri Lanka in ferment : The Philippines as catalyst. Dhaka: IOM.

Adams, C. (1987). Across Seven Seas and Thirteen Rivers: Life Stories of Pioneer Sylheti 
Settlers in Britain, London. Tower Hamlets Art Project.

ADB., \& ILO. (2016). Overseas Employment of Bangladeshi Workers: Trends, Prospects, and Challenges. ADB Briefs No. 63, August.

Afsar, R. (2009). Unravelling the Vicious Cycle of Recruitment: Labour Migration from Bangladesh to the Gulf States. Working Paper. Geneva: International Labour Office, May.

Afsar, R. (2005). Conditional mobility: the migration of Bangladeshi female domestic workers. in S. Huang, B. Yeoh and N. Rahman (eds.). Asian women as transnational domestic workers, Marshall Cavendish Academic, Singapore.

Afsar, R. (2004). Migration from Indian sub-continent to Western Australia: Some intriguing issues of religious composition and political integration. 12th Biennial Conference of the Australian Population Association, Canberra.

Afsar, R. (2003). Dynamics of Poverty, Development and Population Mobility: The Bangladesh Case. Ad Hoc Expert Group Meeting on Migration and
Development, Organised by ESCAP, Bangkok, 27-29 August.

Afsar, R. (2001). Globalization, international migration and the need for networking: the Bangladesh perspective. Bangladesh Institute of Development Studies. Dhaka.

Afsar, R., Yunus, M., \& Islam, S. (2000). Are migrants chasing after the Golden Deer: A study on cost benefit analysis of overseas migration by Bangladeshi Labour, IOM.

Ahmad, A. (2011). Bangladeshi Immigrants. in H. B. Ronald (ed.) Multicultural America: An Encyclopedia of the Newest Americans, 1.

Ahmed, A. (1986). Class and Ethnic Consciousness among the Bangladeshis in Toronto: Historical Basis and Current Pattern. Unpublished Ph.D. Thesis, York University, Toronto.

Ahmed, H. A., \& Uddin, M. G. S. (2009). Export, Imports, Remittance and Growth in Bangladesh: An Empirical Analysis. Trade and Development Review, 2(2), 7992. 
Ahmed, K. A. (2006). Formation of identities of Bangladeshi immigrants in Ottawa. Master's dissertation, Carleton University, Ottawa, Canada.

Ahmed, M. S. (2010). Migrant Workers Remittance and Economic Growth: Evidence from Bangladesh. ASA University Review, 4(1), 1-13.

Ahmed, N. (2005). Women in between: the case of Bangladeshi women living in London. in M. Thapan, (ed.), Transnational Migration and the Politics of Identity, Women and Migration in Asia, 1, 99129.

Ahmed, R., Saha, J. K., Begum, M., \& Haque, M. S. (2018). Impact of foreign remittances on household welfare in Sylhet Region of Bangladesh. Journal of Business and Economic Management, 6(2), 22-32.

Ahmed, S. (1993). Discrimination in Employment and Adaptation: Immigrants Dimension of Bangladeshi Experiences. Master's Theses, York University, Toronto.

Ahmed, S. M. (2012). Migration Remittance and Housing Development: Contribution of International Labor Migration and Remittance to Migrant
Sending Households in Rural Bangladesh. Master Thesis, Lund University.

Ahmed, S. N. (1998). The Impact of the Asian Crisis on Migrant Workers: Bangladesh Perspectives. Asian and Pacific Migration Journal, 7, 2-3.

Ahmed, S., \& Uddin, S. (2005). Conditions in Bangladesh. In Holfman Norbert von (ed). Migrant workers and the Asian economic crisis: towards a trade union position. FreidrichElbert-Stiftung. Office for the Regional Activities in Southeast Asia.

Ahmed, S. R. (2000). Forlorn migrants: An international legal regime for undocumented migrant workers. Dhaka: The University Press Limited.

Ahmad, Q. K., \& Zohora, F. (1997). Utilization of Remittances from Abroad for Local Employment Promotion: The Case of Sylhet. ILO, BUP, Dhaka.

Akbar, M. (2009). Reconstructing the Empowerment Process: Perspectives of Bangladeshi Immigrant Married Women in Toronto, Canada, in Relation to Their Labour Market Integration Process. Master's 
Thesis, Carleton University Ottawa.

Akbory, Y. (2003). Globalization: Public Capacity and Involving Diasporas for Development in Bangladesh. Ministry of Expatriate Welfare and Overseas Employment, Dhaka.

Akram, S. M. (2002). Migrant Workers' Rights and Duties in Destination Countries. in Module on Labour Migration Process for Awareness Campaign through Community Leaders and Activists, Dhaka, RMMRU.

Akram, S. M. R., Rashid, R., \& Titumir, R. (2003). Assessment of migrant workers' vulnerability to HIV/AIDS. HASAB and RMMRU. Dhaka.

Akter, S. (2016). Remittance inflows and its contribution to the economic growth of Bangladesh. J Modern Soc. Cult. Res., Niigata University Graduate School of Contemporary Social Culture, 62(3), 215-245.

Akter, N., Topkara-Sarsu, S., \& Diane, D. (2013). Shadow Economies: Economic Survival Strategies of Toronto Immigrant Communities. Toronto East Local Immigration Partnership workgroup (Action for
Neighbourhood ChangeTaylor Massey, Bangladeshi Canadian Community Services, Chinese Canadian National Council-Toronto Chapter, Neighbourhood Link, Riverdale East African Association, Wood Green Community Services), Toronto: Wellesley Institute.

Alam, F. (1988). Salience of homeland: societal polarization within the Bangladeshi population in Britain, Centre for Research in Ethnic Relations, University of Warwick

Alam, M. F. (2013). Bracing for and embracing difference in America's majority minority metropolis: Bangladeshi immigrant children coming of age in New York City. British Journal of Social Work, 43(4), 631-650.

Al-Azami, S. (2005). Language maintenance and shift among the Bangladeshis in Manchester. Edge Hill, Lancashire: ICDES, Edge Hill University.

Al-Azami, S. (2014) From Bengali to English:

Sequential bilingualism of a secondgeneration British Bangladeshi. International Journal of Bilingual Education 
and Bilingualism, 17(4), 484497.

Alexander, C., Firoz, S., \& Rashid, N. (2010). The Bengali Diaspora in Britain: A review of the literature. London, UK. P 8.

Ali, J. (2000). Changing Identity Constructions among Bangladeshi Muslims in Britain. Centre for the Study of Islam and Christian-Muslim Relations, The University of Birmingham, 6, February.

Ali, S. A. (1981). Labor Migration from Bangladesh to the Middle East. Washington, D.C.: The World Bank, World Bank Staff Working Paper 454.

Ali, M. A. (2014). Socio-economic impact of foreign remittance in Bangladesh. Global Journal of Management and Business Research, 14(5), 44-54.

Ali., \& Ali, S. A. (1981). Labor Migration from Bangladesh to the Middle East. Washington,D.C.: $\quad$ World Bank, Print. World Bank Staff Working Paper; No. 454.

Al Hasan, R. (2006). Harnessing Remittances for Economic Development of Bangladesh. Working Paper Series No. 1, INAFI, April 30.
Aminuzamman, S. M. (2007). Migration of Skilled Nurses from Bangladesh: An Exploratory Study. RMMRU, University of Dhaka, Dhaka www.migrationdrc.org/publica tions/research_reports/Migrati on_of_Skilled_Nurses_from_ Bangladesh.pdf

Al-Mukit, D. M., Shafiullah, A. Z. M., \& Sajib, A. H. (2013). Determination of causality between remittance and import: evidence from Bangladesh. International Journal of Business and Social Science Research, 3(3), 55-62.

A Mu'min, C., Helman, C., \& Greenhalgh, T. (2000) Food beliefs and practices among British Bangladeshis with diabetes: implications for health education. Anthropology \& Medicine, 7(2), 209-226.

Asghar, M. A. (1996). Bangladeshi community organisations in East London. London: Bangla Heritage Limited.

Azad, A. K. (2004). Migrant Workers' Remittances: Can it be a Source of Finance for MicroEnterprise Development in Bangladesh? Paper presented at Asia Pacific Regional Micro Credit Summit Meeting of 
Councils, Dhaka, Bangladesh, February 16-19.

Azam, M., Haseeb, M., \& Samsuddin, S. (2016). The impact of foreign remittances on poverty alleviation: global evidence. Interdisciplinary Approach to Economics and Sociology, 9(1), 264-281.

Baey, G., \& Yeoh, B. (2015). Migration and Precarious Work: Negotiating Debt, Employment, and Livelihood Strategies Amongst Bangladeshi Migrant Men Working in Singapore's Construction Industry. Migrating out of Poverty Working Paper 26.

Bahar, Habibullah, Abdul Awwal Sarker and Ballal Hossain. 2006. "The Flow of Workers' Remittances in Bangladesh:Performance,

Challenges and Policy Options." Draft Working Paper, Bangladesh Bank, Dhaka.

Bal, C. S. (2013). The politics of obedience: Bangladesh construction workers and the migrantlabour regime in Singapore. Ph.D. dissertation, Perth: Murdoch University.

Blackledge, A. (2001). The wrong sort of capital? Bangladeshi women and their children's schooling in Birmingham UK. International Journal of Bilingualism, 5(3), 344-369.

Baluja, K. F. (2003). Gender roles at home and abroad: The adaptation of Bangladeshi immigrants. New York: LFB.

Banik, P., \& Kumar, B. (2019). Impact of information literacy skill on students' academic performance in Bangladesh. International Journal of European Studies, 3 (1), 27-33.

Barai, M. K. (2012). Development dynamics of remittances in Bangladesh. SAGE Open.

Barkat, A., \& Suhrawardy, G. M. (2017). Financial and social costs of migration. Human Development Research Centre (HDRC) In: Thematic Research on Migration and Development. International Organization for Migration (IOM), Dhaka.

Barkat, A., \& Ahmed, S. A. (2014). Skilling the Workforce: Labour Migration and Skills Recognition and Certification in Bangladesh. ILO Country Office for Bangladesh, Dhaka.

Barkat, A., Osman, A., Ahmed, S. A., Suhrawardy, G. M., Gupta, S.K.S., \& Badiuzzaman, M. 
(2017). Bangladesh national strategy and action plan on migration and development and monitoring and evaluation framework. International Organization for Migration (IOM) and Human Development Research Centre (HDRC), Dhaka.

Barkat, A., Osman, A., \& Gupta, S. K. (2014a). In the Corridors of Remittance: Cost and Use of Remittances in Bangladesh. International Labour Organization (ILO) Country Office for Bangladesh, Dhaka

Barkat, A., Osman, A., \& Gupta, S. K. (2014b) Reinforcing Ties: Enhancing Contributions from Bangladeshi Diaspora Members. ILO Country Office for Bangladesh, Dhaka.

Barn, R. (2002). Parenting in a foreign climate: The experiences of Bangladeshi mothers in multiracial Britain. Social Work in Europe, 9(3), 28-38.

Barua, S., Majumdar, M. A., \& Akhtaruzzaman, M. (2007). Determinants of Workers' Remittances in Bangladesh: An Empirical Study. MPRA Paper No. 15080. Munich, Germany.

Beaudouin, P. Y. (2006) Economic Impact of Migration on a Rural Area in Bangladesh. Centre
d'Economie de la Sorbonne, Université de Paris.Avaiable at:

http://dse.univr.it/espe/docume nts/ Papers /G/5/G5_1.pdf

Begum, N., \& Khondaker, M. I. (2008). Immigrant Bangladeshi communities and intergenerational conflict: The need for multicultural education. PAACE Journal of Lifelong Learning, 17, 19-36.

Belanger, D., \& Rahman, M. (2013). Migrating against all the odds: International labour migration of Bangladeshi women. Current Sociology, 61(3), 356373.

Blanchet, T., Razzaque, A., \& Biswas, H. (2005). Documenting the undocumented: femalemigrant workers from Bangladesh. Research paper. Dhaka: Dristi Research Centre.

Blanchet, T. (2002). Beyond Boundaries: A Critical Look at Women Labor Migration and the Trafficking Within. Drishti Research Centre, Submitted to USAID, Dhaka, April.

Bhardwaj, S. (2014). Illegal Bangladeshi Migration: Evaluating India-Bangladesh Approaches. CLAWS Journal, Winter, 59-76. 
Biswas, A. (2015). Human Trafficking Scenario in Bangladesh: Some Concerns. International Journal of Humanities \& Social Science Studies, 1(4), 85-90.

Boer, L. (1981). Migration and social mobility in Bangladesh: The marginalization of peasant migration. The Journal of Social Studies, July(13), 2330.

Bose, R. (2014). Bangladeshi parental ethnotheories in the United Kingdom: Towards cultural collaboration in clinical practice. Clinical Child Psychology and Psychiatry, 19(2), 1-15.

Bruyn, T., \& Wets, J. (2006). Remittances and Development. Conference Report on Migration and Development, International Organization for Migration (IOM).

Bruyn, T., \& Kuddus, U. (2005). Dynamics of Remittance Utilization in Bangladesh. No. 18. IOM Migration Research Series. Geneva: International Organization 69for Migration, January.

Buchman, D. (2013). Accountability at the Local Level in Fragile Contexts: Bangladesh Case Study. Institute of
Development Studies (IDS), IDS Working Paper 419.

Buchenau, J. (2008). Migration, Remittances and Poverty Alleviation in Bangladesh Report and Proposal. UNDPBangladesh Migration and Remittances 080120.doc, January.

Carey, S., \& Shukur, A. (1985). A Profile of the Bangladeshi Community in East London, New Community 12 (3), 405417.

Chalmers, R. (1998). Paths and pitfalls in the exploration of British Bangladeshi identity. In A question of identity (ed) A.J. Kershen Aldershot: Ashgate.

Chakraborty, D. (2004). Emerging status of women migrants from Bangladesh to West Bengal and Orissa during 1971-2001. Centre for Research in IndoBangladesh Relations, Kolkata.

Chowdhury, A. R. (1997). Bangladesh Country Paper on Migrant Workers. Presented at a Regional Meeting of Officials of Labor Exporting Countries, Organized by Sri Lanka Bureau of Foreign Employment in Collaboration with AFLI, March. 
Chowdhury, F.Y., \& Hamid, O. (2016). Language, migration and social wellbeing. A narrative inquiry into the lives of low English proficiency Bangladeshi migrants in Australia. Australian Review of Applied Linguistics, 39(1), 8-30.

Chowdhury, I. A. (2014). Impacts of remittance on the socioeconomic condition of Bangladesh: an analysis. Innovative Issues and Approaches in Social Sciences, 7(3), 23-43.

Chowdhury, K. A. (1995). Emigration and its effects on the labour exporting countries: a review of existing literature. Rajshahi University Studies, C(3).

Chowdhury, K. A. (1992). The Impact of Foreign Remittances on the Receiving and Non-receiving Households in a Bangladesh Village. South Asian Anthropologist, 13(1), 37-42.

Chowdhury, M. (2015). Households' characteristics and the modes of remittances in Bangladesh. Journal of Developing Areas, 49(4), 167-195.

Chowdhury, M. B., \& Rabbi, F. (2014). Workers' remittances and Dutch disease in Bangladesh. The Journal of
International Trade \& Economic Development, 23(4), 455-475.

Chowdhury, M. B. (2011). Remittances flow and financial development in Bangladesh. Economic Modelling, 28(6), 2600-2608.

Chowdhury, K. R., Hamid, F., \& Chatterjee, D. D. (2010). Remittance as a tool of economic development: Bangladesh perspective. Bangladesh Research Publications Journal, 4(3), 286-296.

Chowdhury, N. (2005). The Assimilation of Bengali Immigrants in the United States. .Paper presented at the annual meeting of the American Sociological Association, Philadelphia Hotel, Philadelphia, PA, 12.

Choudhury, Y. (1993). The Routes and Tales of the Bangladeshi Settlers, Birmingham. Sylhet Social History Group.

Dale, A. (2008). Migration, marriage and employment amongst Indian, Pakistani and Bangladeshi residents in the UK. University of Manchester, CCSR Working Paper, 2. 
Dale, A., \& Ahmed, S. (2008). Pakistani and Bangladeshi women's labour market participation. CCSR Paper, 1.

Dale, A., Fieldhouse, E., Shaeen,N., \& V. Kalra, V. (2002). The Labour Market Prospects for Pakistani and Bangladeshi Women. Work, Employment and Society, 16 (1), 5-21.

Dale, A., Shaheen, N., Kalra, V., \& Fieldhouse, E. (2002). Routes into Education and Employment for Young Pakistani and Bangladeshi women in the UK. Ethnic and Racial Studies 25 (6), 942-968

Das, N., Janvry, A., Mahmood, S., \& Sadoulet, E. (2014). Migration as a Risky Enterprise: A Diagnostic for Bangladesh. CUDARE Working Papers, University of California, Berkley.

Das, A., \& Chowdhury, A. (2011). Remittances and GDP Dynamics in 11 Developing Countries: Evidence from Panel Cointegration and PMG Technique. Romanian Economic Journal, 14, 3-24.

Datta, P. (2004). Push-pull factors of undocumented migration from Bangladesh to West Bengal: A perception study. The
Qualitative Report, 9(2), 335358.

Datta, K., \& Sarkar, B. (2014). Relationship between Remittances and Economic Growth in Bangladesh: An Econometric Study. Bangladesh Development Research Working Paper Series (BDRWPS), BDRWPS 19.

Dannecker, P. (2005). Transnational Migration and the Transformation of gender relations: the Case of Bangladeshi Labour Migrants. Current Sociology, 53(2), 655674.

Dannecker, P. (2004). Bangladeshi migrant workers in Malaysia: The construction of the 'others' in a multi-ethnic context. Asian Journal of Social Science, 33(2), 246-267.

Dannecker P. (2003). The construction of the myth of Malaysia: labour migration from Bangladesh to Malaysia. University of Belfield. Working paper no. 345. Bielefeld.

Dannecker, P. (1999). Conformity or resistance: women workers in the garment factories in Bangladesh. Working paper. Sociology of Development Research Centre. No 326. University of Bielefeld. 
Das, J., \& Talukdar, D. (2016). SocioEconomic and Political Consequence of Illegal Migration into Assam from Bangladesh. Journal of Tourism \& Hospitality, 5(2), 25.

Deka, A. K. (2011). Migration and Conflict: A Comparative Study of Bangladeshi and Nepali Migrants in Assam. Doctoral thesis) JNU, South Asian Studies Division, New Delhi.

DCLG. (2009). The Bangladeshi Muslim Community in England: Understanding Muslim Ethnic Communities. Department of Communities and Local Government, Available online: http://www.communities.gov.u k/documents/communities/pdf/ 1203189.pdf

Dutta, G. (2013). Bangladeshi Migrants in India: Issues and Government Responses. Online International Interdisciplinary Journal, 3(6), 499-507.

Eade, J. (2004) 'Living the Globalizing City: Globalization in the Context of European Urban Development' in Eckardt, F. \& Hassenpflug, D. (eds) Urbanism and Globalization, Frankfurt: Peter Lang
Eade, J. (1998). The search for wholeness: the construction of national and Islamic identities among British Bangladeshis. In A question of identity (ed) A.J. Kershen. Aldershot: Ashgate.

Eade, J. (1997a). Identity, Nation and Religion: Educated Young Bangladeshis in London's East End' in Eade, J. (ed) Living the Global City: Globalization as Social Process, London: Routledge.

Eade, J. (1997b). Keeping the Options Open: Bangladeshis in a Global City in London, the Promised Land? : the migrant experience in a capital city, Anne J. Kershen, ed. 91-110, Aldershot, Hants. : Avebury.

Eade, J. (1994). Identity, Nation and Religion: Educated young Bangladeshi Muslims in London's East End. International Sociology, 9 (3), 377-94.

Eade, J. (1990). Nationalism and the Quest for Authenticity: The Bangladeshies in Tower Hamlets. New Community, 16(4), 493-503.

Eade, J. (1989). The Politics of Community: The Bangladeshi Community in East London, Aldershot: Avebury. 
Eade, J., \& Garbin, D. (2002). Changing Narratives of Violence, Struggle and Resistance: Bangladeshis and the Competition for Resources in the Global City. Oxford Development Studies, 30(2), 137-151.

Eade, J., \& Momen, R. (1995). Bangladeshis in Britain: a national database. London: CBS.

Eade, J., Vamplew, T., \& Peach, C. (1996). The Bangladeshis: the encapsulated community. in Ethnicity in the 1991 Census, vol 2, The Ethnic Minority Populations of Britain .London: Office for National Statistics, Peach C, ed., 150160.

Ellickson, J. (2002). Local Saint vs. Cotemporary Reformer: Religious Trends in Bangladesh. Alam S.M (Eds). In Cotemporary Anthropology: Theory and Practice. Dhaka: Jahangirnagar University and University Press Limited.

Equal Opportunities Commission (2006). Moving On Up? Bangladeshi, Pakistani and Black Caribbean Women and Work, London: Equal Opportunities Commission.
Faraizi, A. H. (1993). Bangladesh: Peasant migration and the world capitalist economy, New Delhi: Sterling Publishers.

Farhana, K. M., \& Mannan, K. A. (2018a). Socioeconomic impact of rural urban migration: A revisit of slum dwellers in northern region of Bangladesh. International Journal of Migration and Development, 5(3), 41-57.

Farhana, K. M., \& Mannan, K. A. (2018b). Determinants of Regional Rural Urban Migration in Bangladesh: A Model Test on Marginal Segment in Rajshahi City. International Journal of Migration and Development, 4(3), 22-33.

Farid, K., Mozumdar, L., Kabir, M., \& Hossain, K. (2009). Trends in international migration and remittance flows: Case of Bangladesh. Journal of Bangladesh Agricultural University, 7(2), 387-394.

Faroque, O., Islam, M., Rahman, M., \& Islam, M. (2013). Maternity Benefit Practices at NGOs in Bangladesh: Laws and Implementation. Beijing Law Review, 4(4), 168-173. 
Faruque, M. O. (2006). International instruments and Bangladesh's migrant workers' rights: obligations, initiatives, and challenges. Dhaka: RMMRU.

Flagstad, B. K. (2000). Gender Role Attitudes among Bangladeshi Immigrants: an origin and destination area study. $\mathrm{PhD}$ thesis, The Pennsylvania State University.

Firoze, F. (1997). Trafficking in Women and Children: A Bangladesh Perspective. Paper presented at a Conference on Women Migrant Workers organized by Regional Office of International Solidarity Center, Colombo, Sri Lanka, October 7-9.

Foo, D. S. P. (1999). On foreign soil: A study of Bangladeshi workers in Singapore. Honours thesis). Department of Sociology, National University of Singapore.

Garbin, D. (2009). Identities and 'new ethnicities' among British Bangladeshi and mixed heritage youth. London: CRONEM/University of Surrey.

Gardner, K. (1998). Identity, age and masculinity amongst Bengali elders in East London. In A question of identity (ed) A.J. Kershen. Aldershot: Ashgate.

Gardner, K. (1995). Global Migrants, Local Lives: Travel and Transformation in Rural Bangladesh: Travel and Transformation in Rural Bangladesh. Clarendon Press.

Gardner, K. (1993a). Desh-bidesh: Sylheti images of home and away. Man (N.S.) 28, 1-15.

Gardner, K. (1993b). Mullahs, Migrants, Miracles: Travel and Transformation in Sylhet. Contributions to Indian Sociology, 27, 213-235.

Gardner, K. (2002a). Age, Narrative and Migration: The Life Course and Life Histrories of Bengali Elders in London. Oxford: BERG

Gardner, K. (1992b). International Migration and the Rural Context in Sylhet. New Community, 18(4): 579-590

Gardner, K. (1990). Paddy Fields and Jumbo Jets: Outmigration and Village Life in Sylhet District, Bangladesh. Thesis, University of London

Gardner, K., \& Ahmed, Z. (2006). Place, Social Protection and Migration in Bangladesh: A Londoni Village in Biswanath. Sussex Working Paper. T 18. 
Gardner, K., \& Shukur, A. (1994). I'm Bengali, I'm Asian, and I'm living here': The changing identity of British Bengalis. In R. Ballard (Ed.). Desh pardesh: The south Asian presence in Britain (pp.142-164). London: Hurst.

Gavron, K. (1997). Migrations to Citizens: Changing Orientations among Bangladeshis of Tower Hamlets. Thesis; University of London.

Ghelli, N. (2018). Reducing poverty through migration in Bangladesh. BORGEN Magazine. Retrieved from: http://www.borgenmagazine.c om/reducing-povertythroughmigration-bangladesh/.

Ghosh, B. (2005). Economic effects of international migration: A synoptic overview. In I. Omelaniuk . (Ed.), World migration 2005: Cost and benefits on international migration, 161-183, Geneva, Switzerland: International Organization for Migration.

Ghosh, P. (1993). Bangladesh at Crossroads: Religion and Politics. Asian Survey, 33(7), 697-710

Ghosh, S. (2014). Everyday Lives in Vertical Neighbourhoods:
Exploring Bangladeshi

Residential Spaces in Toronto's Inner Suburbs. International Journal of Urban and Regional Research, 38(6), 2008-2024.

Ghosh, S. (2007). Transnational ties and intra-immigrant group settlement experiences: A case of Indian Bengalis and Bangladeshis in Toronto. Geo Journal, 68, 223-242.

Ghosh, S. (2006). We are not all the same: The differential migration, settlement patterns, and housing trajectories of Indian Bengalis and Bangladeshis in Toronto. Doctoral dissertation, PhD Thesis, York University, Toronto, Canada.

Gillan, M. (2002). Refugees or infiltrators? The Bharatiya Janata Party and 'illegal' migration from Bangladesh. Asian Studies Review. 29(1), 73-95.

GoB-ILO. (2015). The homecoming: Profiling the returning migrant workers of Bangladesh. Dhaka: International Labour Organization and ILO Country Office for Bangladesh.

GoB-ILO. (2014). Gender and migration from Bangladesh Mainstreaming migration into the national development plans 
from a gender perspective. ILO Country Office for Bangladesh: International Labour Organization.

Greenhalgh, T., Helman, C., \& Mu'min, A. C. (1998). Health Beliefs and folk models of diabetes in British Bangladeshis: a qualitative study. British Medical Journal, 316, 978-983

Habib, A. (1985). Economic Consequences of International Migration for Sending Countries: Review of Evidence from Bangladesh. Ph.D. thesis, Department of Economics, University of Newcastle, Australia.

Hadi, A. (2001). International migration and the change of women's position among the left-behind in rural Bangladesh. International Journal of Population Geography, 7, 53-61.

Hadi, A. (1999). Overseas Migration and the Welling-being of Those Left Behind in Rural Communities of Bangladesh. Asia-Pacific Population Journal, 14(1), 43-58.

Haider, M. Z., Hossain, T., \& Siddiqui, O. I. (2016). Impact of remittance on consumption and savings behavior in rural areas of Bangladesh. Journal of Business, 1(4), 25-34.

Halder, R., (2012). Immigration and Identity Negotiation within the Bangladeshi Immigrant Community in Toronto, Canada. Doctoral dissertation, University of Manitoba.

Haque K. H. (2008). Bengali-speaking families in Singapore: Home, Nation, and the World. International Migration, 46 (4), 177-1998.

Haque, F. (2006). General Overview of Inflow of Remittance in Bangladesh Economy. Internship Report, Independent University, Bangladesh.

Haque, C. E. (1984). Labor Migration from Bangladesh to the Middle East: Development or Dependency?. In Mohammad Mohabbat Khan and John P. Thorp (Ed.) Bangladesh: Society, Politics and Bureaucracy, Center for Administrative Studies, Dhaka

Hassan, G, \& Mark, H. (2013). Remittances and the Real Effective Exchange Rate. Applied Economics, 45, 495970.

Hassan, G., \& Shakur, S. (2017). Nonlinear effects of remittances on per capita GDP 
growth in Bangladesh.

Economies, 5 (3), 25.

Hassan, G. M., Chowdhury, M., \& Bhuyan, M. (2016). Growth effects of remittances in Bangladesh: Is there a Ushaped relationship?. International Migration, 54(5), 105-121.

Hassan, M. (2000). Complementarity between international migration and trade: a case study of Bangladesh. Journal of Bangladesh Studies, 1(2).

Hasan, M. R. (2009). International Labour Migration Governance: The Case of Bangladesh. MA Thesis, Institute of Governance Studies, BRAC University, Dhaka, November.

Hasan, R. A. (2006). Harnessing remittances for economic development of Bangladesh. Working Paper Series No.1. INAFI Bangladesh: Dhaka.

Hatemi-J, A., \& Uddin, G. S. (2014).

On the causal nexus of remittances and poverty reduction in Bangladesh. Applied Economics, 46(1), 374-382.

Hazarika, S. (2000). Rits of Passage: Border Crossing, Imagined Homelands, India's East and
Bangladesh. Haryana: Penguin Books.

Higuchi, N. (2007). Remittances, investments and social mobility among Bangladeshi and Iranian returnees from Japan. In: Proceedings for the 8th Asia and Pacific Migration Research Network Conference on Migration, Development and Poverty Reduction.

Hossain, A. A. M. (1986). The International Labor Migration to the Middle East: The Impact and Consequences for the Social Structure of a Sender Country: the Case of Bangladesh. Ph.D. Dissertation, University of California Riverside.

Hussain, A. R. M. (1979). Migration of Labour from Bangladesh. Dhaka: Bureau of Manpower, Employment, and Training, Government of the People's Republic of Bangladesh.

ILO (International Labor Organization). (2010). Study on the International Demand for Semi-skilled and Skilled Bangladeshi Workers. TVET Reform Project Report, Dhaka: Maxwell Stamp Limited.

ILO. (1980). Policy Implications for Bangladesh in Promoting Overseas Employment. 
Bangkok: ILO/ARPLA, Asian

Regional Programme for

Labour Administration.

INSTRAW/IOM. (2000). Temporary

Labour Migration of Women:

Case Studies of Bangladesh and Sri Lanka. Dominican Republic: INSTRAW.

IOM (International Organization for Migration Bangladesh). (2017). Social Cost of Migration on Children Left Behind due to Labour Migration. Dhaka: IOM.

IOM (2016). Facts and Figures of Bangladeshi Migrants.

IOM. 2014. Gender and Migration from Bangladesh: Mainstreaming Migration into the National Development Plans from a Gender Perspective.

http://www.ilo.org/dhaka/Wha twedo/Publications/ WCMS_310411/lang-en/index.htm

IOM (2010). The Bangladesh Remittance Households Survey 2009 Summary Report. Dhaka: IOM.

IOM (2009). Remittances: Definition, Scale, and Importance of Remittances.

Iredale, R., \& Guo, F. (2001). The Transforming Role of Skilled and Business Returnees: Taiwan, China and Bangladesh. (MS) Wollongong: University of Wollongong, Centre for Asia Pacific Social Transformation Studies (CAPSTRANS).

Ishida, A., \& Hassan, M. S. (2000). Why Do Migrant Workers Intend to Extend Their Stay in Host Countries? The Case of Bangladeshi Workers in Malaysia's Manufacturing Sector. International Migration, 38(5), 100-115.

Islam, M., Hasanuzzaman C., Salehuddin, J., Dutta, P., Ali, M., \& Enamul, H. (1987). Overseas Migration from Rural Bangladesh: a Micro Study, Chittagong: Rural Economics Programme, Department of Economics, University of Chittagong.

Islam, M. (1995). Bangladeshi Migration: An Impact Study. in Robin Cohen (ed.), The Cambridge Survey of World Migration, Cambridge University Press: Cambridge

Islam, M. (1991). Labor Migration and Development: A Case Study of a Rural Community in Bangladesh. Bangladesh Journal of Political economy, 11(2), 570-587. 
Islam, M. (1988). Overseas Migration from Rural Bangladesh: Effect on some Agrarian Relations in the Sending Communities. Migration, 88 (3), 5-28.

Islam, M. A., \& Rayhan, M. I. (2016). Impact of remittances on poverty: an analysis of developing countries. Global Journal of Quantitative Science, 3(4), 9-13.

Islam, M. S. (1997). Bangladeshi Immigrants in Toronto: Towards An Alternative Way to Meet Cultural Needs, The Journal of Social Studies, 5770 .

Islam, M. D. (1991). Labour migration and development: A case study of a rural community in Bangladesh. Bangladesh Journal of Political Economy, 11(2B), 570-87.

Islam, M. N. (2007). Migration Scenario: Nature, Patterns and Trends. Dhaka: Bureau of Manpower, Employment and Training.

Islam, N. (1981). Islam and National Identity: The Case of Pakistan and Bangladesh. In International Journal of Middle East Studies, 13(1). 55-72.

Islam, N. (2014). Migration Scenario: Nature, Patterns and Trends.
Dhaka: Bangladesh Bureau of Manpower Employment and Training.

Islam, N. (2011). Bangladesh Expatriate Workers and their Contribution to National Development. Dhaka: Bangladesh Manpower Employment and Training.

Islam, T. S., Wadud, M. A., \& Islam, Q. B. T. (2007). Relationship between education and GDP growth: A multivariate causality analysis for Bangladesh. Economics Bulletin, 3(35), 1-7.

Islam, R. (1980). Export of Manpower from Bangladesh to the Middle East: The Impact of Remittance Money on Household Expenditure. National Foundation for Research on Human Resource Development, Dhaka.

Islam, S., \& Parvin, S., \& Kalam A. (2013). Socio economic impacts of international migration in Bangladesh. Journal of Economics and Sustainable Development, 4(4), 9-17.

Ishtiaque, A., \& Ullah, M. S. (2013). The influence of factors of migration on the migration status of rural-urban migrants 
in Dhaka. Bangladesh. Human Geographies, 7(2), 45-52.

Iqbal, M. (2014). Citizens of the world: The integration of transnationally connected Bangladeshi and Pakistani immigrants into Australian society. Doctoral dissertation, RMIT University, VIC, Australia.

Joarder, M. A. M., \& Hasanuzzaman, S. (2008). Migration decision from Bangladesh: Permanent versus temporary. Asia Europe Journal, 6(3-4), 531-545.

Joarder, M., Munim, A., \& Paul W. M. (2014). Empirical Evidence on Human Trafficking and Migration-debt Contracts in Bangladesh. Journal of Development Studies, 50(3), 399-412.

Joshi, S. (2004). Female Householdheadship in Rural Bangladesh: Incidence, Determinants and Impact on Children's Schooling. Economic Growth Centre Discussion Paper No: 894, Yale University.

Kibria, N. (2013). Bangladeshis and Bangladeshi Americans, 1940Present. In E. R. Barkan (Ed.). Immigrants in American history: Arrival, adaptation, and integration (pp.747-757).
Santa Barbara, CA: ABCCLIO.

Kibria, N. (2011a). Muslims in motion: Islam and national identity in the Bangladeshi diaspora. New Brunswick: Rutgers University Press.

Kibria, N. (2011b). Working hard for the money: Bangladesh faces challenges of large-scale labor migration. Migration Information Source, August. Washington: Migration Policy Institute.

Kibria N. (2010). The 'Invisible Family' of Globalization Theory." In At the Heart of Work and Family: Engaging the Concepts of Arlie Russell Hochschild. Eds, A. Garey and K. Hansen. Rutgers University Press.

Kibria, N. (2009). Marry into a good family: Transnational reproduction and intergenerational relations in Bangladeshi American families. In N. Foner (Ed.), Across generations: Immigrant families in America (pp. 98113). New York: NYU Press.

Kibria, N. (2008). The 'new Islam' and Bangladeshi youth in Britain and the US. Ethnic and Racial Studies, 31(2), 243-266. 
Kibria N. (2007). South Asia: Pakistan, Bangladesh, Sri Lanka, Nepal. In The New Americans: A Guide to Immigration Since 1965. Eds. M. C. Waters and R. Ueda. Cambridge, MA: Harvard University Press. Pp. 612-623.

Kibria N. (2006). Globalization and the Family: Introduction to the Special Issue. In International Journal of Sociology of the Family, 32(2), 137-139.

Kibria N. (2005). South Asian Americans. In Asian Americans: Contemporary Trends and Issues. Ed Pyong Gap Min. Beverly Hills, CA: Sage Publications.

Kibria N. (2004a). Globalization, labour standards and women's rights: dilemmas of collective (in) action in an interdependent world. Feminist Economics, 10(1), 3-35.

Kibria N. (2004b). Returning International Labor Migrants from Bangladesh: The Experience and Effects of Deportation. University of Boston. Department of Sociology Working Paper No. 28. USA.

Kibria N. (2000). The Power to Choose: Bangladeshi Women and Labour Market Decisions in London and Dhaka, London: Verso

Kibria N. (1997). Women, wages, and intra-household power relations in urban Bangladesh. Development and Change. 28, 261-302.

Kibria N. (1988). Subordination and Struggle: the Women's movement in Bangladesh. New Left Review, no.168 (March/ April).

Karim, M. R. (2020). Overseas employment and sustainable development goals in Bangladesh: Connectedness, contribution and achievement confusion. Bangladesh Journal of Public Administration, 28(Special Issue), 70-71.

Karim, A. H. M. Z., Abdullah, M. A., \& Bakar, M. I. H. (1999). Foreign Workers in Malaysia: Issues and Implications, Utusan Publications: Kuala Lumpur.

Kershen, A. (2005). Strangers, Aliens and Asians: Huguenots, Jews and Bangladeshis in Spitalfields, 1660-2000, London: Routledge.

Khan, Z. S., \& Islam, S. (2013). The effects of remittances on inflation: evidence from Bangladesh. Journal of 
Economics and Business

Research, 19(2), 198-208.

Khan, M. A., \& Richardson, J. (2013).

Health and quality of life of Bangladesh migrants in Melbourne-an analysis with four multi-attribute utility and three subjective wellbeing instruments. Journal of Management and Sustainability, 3 (4), 53-66.

Khan, M. W. R., (2008). The Micro Level Impact of Foreign Remittances on Incomes in Bangladesh: A Measurement Approach Using the Propensity Score. Centre for Policy Dialogue: Dhaka.

Khanum, S. M. (2001). The Household Patterns of a Bangladeshi Village in England. Journal of Ethnic and Migration Studies, 27 (3), 489-504.

Khattab, N., Johnston, R., Sirkeci, I., \& Modood, T. (2010). The Impact of Spatial Segregation on the Employment Outcomes amongst Bangladeshi Men and Women in England and Wales. Sociological Research Online, 15(1), 24-36.

Khoda, M. E., \& Shahzada. A. M. (2017). Good Governance in the Labour Migration Process: Challenges and the Way Forward. Transparency
International Bangladesh, March 9.

Khonkder, H. H. (2008). Bengalispeaking families in Singapore: Home, nation and the world. International Migration, 46(4), 173-197.

Khondker, H. H. (1995). Politics, Disaster and Refugees: The Bangladesh Case. in Ong Jin Hui et al. (ed.), Crossing Borders: Transmigration in Asia Pacific, Prentice Hall: New York.

Khondokar, H. (2004). New Trends and Changing Landscape of Bangladeshi Migration. in $\mathrm{H}$. Oda (ed.), International Migration from South Asia, Institute of Developing Economies, Chiba, Japan.

Khondaker, M. (2007). Juvenile deviant behavior in an immigrant Bangladeshi community: Exploring the nature and contributing factors. International Journal of Criminal Justice Sciences, 2(1), 27-43.

Khandker, S. R., Koolwal, G. B., \& Samad, H. A. (2010). Handbook on Impact Evaluation: Quantitative Methods and Practices, the International Bank for 
Reconstruction

and

Development/the World Bank.

Kotalova, J. (1996). Belonging to others: Cultural construction of womanhood in a village in Bangladesh. Dhaka: University Press.

King, R., \& Knights, M. (1994). Bangladeshis in Rome: A Case of Migratory Opportunism" in W.T.S. Gould and A.M. Findlay (ed.), Population Migration and the Changing World Order, Chiehester, England, 1994.

Knights, M. (1996). Migration in the New World Order: the Case of Bangladeshi Migration to Rome. Ph.D. thesis, University of Sussex.

Kuddus, U. M. (2003). Channeling Diaspora Remittance into the Securities Market of Bangladesh, internship report for IOM, Institute of Business Administration, University of Dhaka, Dhaka.

Kuhn, R. (2001). Never Far from Home: Parental Assets and Migrant Transfers in Matlab, Bangladesh. Working Paper Series 1-12, Labor and Population Program, RAND. Retrieved from http://www.dtic.mil/docs/citati ons/ADA394789
Kuhn, R. (1999). The Logic of Letting Go: Family and Individual Migration From Rural Bangladesh. Ph. D. Thesis, University of Pennsylvania.

Kuhn, R. (2003). Identities in Motion: Social exchange networks and rural-urban migration in Bangladesh. Contribution to Indian Sociology, 37(1), 281311 .

Kuhn, R., \& Meneen J. A. (2002). Migrant social capital and education in migrantsending areas of Bangladesh: complements or substitutes?. University of ColoradoInstitute of Behavioral Science. Available at: http://ibs.colorado.edu/ kuhnr/ pdf/mig-ed

Kumar, B. (2019). The impact of international remittances on poverty alleviation in Bangladesh. Remittances Review, 4 (1), 67-86.

Kumar, B., Hossain, M. E., \& Osmani, M. A. G. (2018). Utilization international remittances in Bangladesh. Remittances Review, 3 (1), 5-18.

Kumari, R., \& Shamim, I. (2010). Gender Dimensions of International Migration from Bangladesh and India: Socio Economic Impact on Families 
Left Behind. Available at: http://www.saneinetwork.net/F iles/10_07__Ranjana_Kumari .pd

Kundu, N. (2016). An enquiry into the sluggish growth of workers' remittance determinants: a case of Comilla. Journal of Economics and Business Research, 22 (1), 152-167.

Lawson, S., \& Sachdev, I. (2004). Identity, Language use, and attitudes: Some SylhetiBangladeshi Data from London, UK. Journal of Language and Social Psychology, 23(1), 49-69.

Lian, K. F., \& Rahman, M. M. (2006). International labor recruitment: Channeling Bangladeshi migrants to East and Southeast Asia. Asia-Pacific Population Journal, 21(1), 85-107.

Lie, M. L. S. (2011). Across the oceans: Child care and grandparenting in UK Chinese and Bangladeshi households. Journal of Ethnic and Migration Studies, 36(9), 14251443.

Mahmud, H. (2017). Social determinants of remitting practices among Bangladeshi migrants in Japan. Sociological Perspectives 60 (1), 95-112.
Mahmud, H. (2014). It's my money: Social class and the perception of remittance among Bangladeshi migrants in Japan. Current Sociology, 62(3), 418430 .

Mahmud, W., \& Osmani, S. R. (1980). Impact of Emigrant Worker's Remittance on the Bangladesh Economy. Bangladesh Development 8(3).

Mahmood, R. A. (1998). Bangladeshi clandestine foreign workers. In R. Appleyard (Ed.). Emigration dynamics in developing countries, Volume II: South Asia. Singapore: Ashgate.

Mahmood, R. A. (1996). Immigration Dynamics in Bangladesh: Level, Pattern and Implications. Paper presented for the Asiatic Society of Bangladesh, Dhaka.

Mahmood, R.A. (1995). Emigration Dynamics in Bangladesh. International Migration, 33(3), 699-726.

Mahmood, R. A. (1994a). Analysis of Present and Future Emigration Dynamics in Bangladesh. Bangladesh Institute of Development Studies.

Mahmood, R. A. (1994b) Adaptation to a New World: Experience of Bangladeshis in Japan. 
International Migration, 32(4), 194.

Mahmood, R. A. (1992). Bangladeshi Returned Migrants from the Middle East: Process, Achivement, and Adjustment. In G. Gunatilleke (Ed.) The Impact of Labor Migration on Households: A Comparative Study in Several Asian Countries. Tokyo: United Nations University Press.

Mahmood, R. A. (1991). International Migration and Development: Untapped Potentials for Bangladesh. Bangladesh Institute of International and Strategic Studies, 12(4), 526557.

Mahmood, R. (1991). Employment of Bangladeshis Abroad and Uses of Their Remittances. A report prepared for the Planning Commission, Government of the People's Republic of Bangladesh.

Mahmud, W. (2003). Bangladesh: Development outcomes and challenges in the context of globalization. Conference on the Future of Globalization, Oct 10-11, Yale University.

Majumder, S. C. (2016). Inflation and its impacts on the economic growth of Bangladesh.
American Journal of Marketing Research, 2(1), 17-26.

Mamun, K. \& Nath, H. K. (2010). Workers' migration and remittances in Bangladesh. Journal of Business Strategies, 27(1), 29-52.

Mannan, N., \& Boucher, B. J. (2002). The Bangladeshi Diaspora and its Dietary Profile in East London 1990 - 2000. in Food in the migrant experience, Anne J.Kershen, ed., Ashgate, Aldershot, 229-243.

Mannan M. A. (2001). Bangladeshi Migrants in Saudi Labour Market: an Empirical Analysis. RMMRU. Dhaka.

Mannan, K. A. (2020). The Theory of Matriarchism: The Universal Origin of Human. Asian Journal of Indigenous Studies, 6(1), 22-53.

Mannan, K. A. (2017a). Remittance model: a study of developing country in Bangladesh. International Research Journal of Business and Social Science, 3 (3), 35-50.

Mannan, K. A. (2017b). Bangladeshi migration to Italy: an analysis of motivational factors and process. International Journal of Migration and Development, 3(3), 39-50. 
Mannan, K. A. (2017c). The Rohingya issue and international migration: a historical perspective. Asian Journal of Indigenous, 3(2), 32-43.

Mannan, K. A. (2017d). Macro determinants of remittance: Relationship between remittance and economic growth in Bangladesh. International Research Journal of Business and Social Science, 3(2), 35-44.

Mannan, K. A. (2017e). Motivations for Remittances: A Study of Rural Bangladesh Migrants in Italy. International Journal of Migration and Development, 3(2), 38-41.

Mannan, K. A. (2016a). Labour migration between developing economy to developing country: A case study of Bangladesh and Malaysia. International Journal of Migration and Development, 2(3), 41-56.

Mannan, K. A. (2016b). Determinants and socioeconomic impacts of migrant remittances: A study of rural Bangladeshi migrants in Italy. DBA Thesis, Southern Cross University, NSW, Australia.
Mannan, K. A. (2011a). 'Forthcoming '6P' and Bangladeshi Migrant Workers in Malaysia', The 24th LAWASIA Annual Conference in Seoul, Hosted by Korean Bar Association, 1112th October, Seoul, South Korea.

Mannan, K. A. (2011b). Bangladeshi Emigration Opportunities Worldwide', Annual Conference of International Bar Association, 30 October04 November, Dubai, UAE.

Mannan, K. A. (2010). The Rights of migrant workers including illegal immigrants: Bangladeshi migration workers problems in Malaysia. 7th LAWASIA Labour Law Conference in Hong Kong, Supported by the Law Society of Hong Kong and Hong Kong Academy of Law 17-18 September 2010, Hong Kong.

Mannan, K. A., Chowdhury, G. M. O. F., \& Farhana, K. M. (2020). The COVID-19 Pandemic Impacts on Manpower Export: An Econometric Analysis of Survival Strategies of Recruiting Agencies in Bangladesh. The Cost and Management, 48(03), 25-34. 
Mannan, K. A., \& Fredericks, L. J. (2015a). The New Economics of Labour Migration (NELM): Econometric Analysis of Remittances from Italy to Rural Bangladesh Based on Kinship Relation. International Journal of Migration and Development, 1(1), 01-21.

Mannan, K. A., \& Fredericks, L. J. (2015b). Determinants and socioeconomic impact of remittances between Bangladesh and Italy: A multivariate analysis of religion of rural households. International Research Journal of Business and Social Science, $1(1), 22-42$.

Mannan, K. A., \& Farhana, K. M. (2020). Migration, Diasporas, Remittances and the Sustainable Development Goals in Bangladesh. International E-Conference on 'Migration, Diasporas and Sustainable Development: Perspectives, Policies, Opportunities and Challenges',Jointly Organized by Global Research Forum on Diaspora and Transnationalism (GRFDT), New Delhi, India, Center for Research on North America (CISAN), National Autonomous University of Mexico (UNAM), Migrant Forum in Asia (MFA), Manila,
Philippines, Cross-Regional Center for Refugees and Migrants (CCRM), Beirut, Lebanon are jointly organising an International E-Conference on "Migration, Diasporas and Sustainable Development: Perspectives, Policies, Opportunities and Challenges" 2-5 November.

Mannan, K. A., \& Farhana, K. M. (2018). Socioeconomic impact of regional rural urban migration: A revisit of slum dwellers of Rajshahi City Corporation, National Seminar on Change, Continuity, And The Marginals In Bangladesh, January 05-06, 2018, ASHRAI Research and Training Centre (ARTC), Baya, Rajshahi, Bangladesh, Institute of Social Research and Applied Anthropology (ISRAA), Rajshahi \& Department of Anthropology, University of Rajshahi.

Mannan, K. A., \& Farhana, K. M. (2015a). 'Determinants of remittances in rural Bangladesh: An econometric analysis of the educational attainments of the household members. Research Journal of Social Science and Management, 4(12), 177-198. 
Mannan, K. A., \& Farhana, K. M. (2015b). An arithmetic analysis of Bangladeshi sending migrants stock and remittance per capita in Malaysia. Research Journal of Social Science and Management, 4(10), 146-16.

Mannan, K. A., \& Farhana, K. M. (2015c). Household unit analysis of remittance determinants from Italy to Bangladesh: A study of Shariatpur District, Vogeshore Union. Research Journal of Social Science and Management, 4(9), 159-173.

Mannan, K. A., \& Farhana, K. M. (2014a). Migration Laws, Policies and Economics in Europe: An Empirical Study of Legal Status, Remittances and Scio-economic Impacts in Rural Bangladeshi Households. Lap Lambert Academic Publishing, Saarbrucken, ISBN-13: 978-3659-62822-1, ISBN-10: $3659628220 \quad$ EAN: 9783659628221, Number of page: 128 , Germany.
Mannan, K. A., \& Farhana, K. M. (2014b). Socio-economic impact of remittances from Italy: An empirical study of rural household head relation to the migrant in Bangladesh. International Journal of Management Sciences and Business Research, 3(12), 1729.

Mannan, K. A., \& Farhana, K. M. (2014c). Micro determinants of international remittances: A household unit analysis of marital status of rural household members in Bangladesh. Research Journal of Social Science and Management, 4(8), 47-61.

Mannan, K. A., \& Farhana, K. M. (2014d). Socio-economic impact of remittances in rural Bangladesh: A unit analysis of the age of household head. Research Journal of Social Science and Management, 4(7), 100-118.

Mannan, K. A., \& Farhana, K. M. (2014e). Rural household employment status and remittance inflows from Italy. International Journal of Management Sciences and Business Research, 3(9), 7689. 
Mannan, K. A., \& Farhana, K. M. (2014f). Legal status, remittances and socioeconomic impacts on rural household in Bangladesh: An empirical study of Bangladeshi migrants in Italy. International Journal of Management Sciences and Business Research, 3(8), 52- 72.

Mannan, K. A., \& Farhana, K. M. (2014g). Remittance Micro Determinants and Socioeconomic Impacts: A Household Unit Analysis of Gender Behaviour of Rural Household Head in Bangladesh. International Journal of Management Sciences and Business Research, 3(7), 81-93.

Mannan, K. A., Farhana, K. M., \& Chowdhury, T. A. K. (2014). Rural Household Contribution to the Financial and Capital Market in Bangladesh: A Micro Level Study of Remittances from Italy. International Journal of Management Sciences and Business Research. 3(10), 112122.
Mannan, K. A., \& Wei, G. K. (2009). How Do Migrants' Choice of Remittance Channel? The Case of Bangladesh. Asian Migration and Diaspora Studies, 15(2), 33-56.

Mannan, K. A., \& Wei, G. K. (2008). Why Remit? The Case of Bangladesh. Asian Migration and Diaspora Studies, 14(2), 55-75.

Mannan, K. A., \& Wei, G. K. (2007). Who Remits? The Case of Bangladesh. Asian Migration and Diaspora Studies, 13(2), 43-60.

Mannan, K. A., \& Wei, G. K. (2006). International Remittances, Household Spending, and Investment: A Case Study of Bangladesh. Asian Migration and Diaspora Studies, 12(2), 36-54.

Mannan, K. A., \& Kozlov, V. V. (2005). The Impact of Remittances on Labour Force in Bangladesh: An Empirical Analysis of Labour Participation and Employment. Russian Management Journal, 16(2), 51-74. 
Mannan, K. A., \& Kozlov, V. V. (2003). Bangladeshi Migrants in Italy: An Analysis of Survival Strategies and Job Segmentations. Russian Management Journal, 14(2), 37-57.

Mannan, K. A., \& Kozlov, V. V. (2001). The Cost-Benefit Analysis of International Migration: Modelling and Empirical Study between Bangladesh and Italy. Russian Management Journal, 12(2), 29-52.

Mannan, K. A., \& Kozlov, V. V. (1999). Migration DecisionMaking among Bangladeshi Migrants in Italy: A Combined Model Approach. Russian Management Journal, 10 (2), 19-42.

Mannan, K. A., \& Kozlov, V. V. (1997). Transits and Transnational Route of Migration and Trafficking: A Journey from Bangladesh to Italy via Moscow, Russia. Russian Management Journal, 8 (2), 27-48.
Mannan, K. A., \& Kozlov, V. V. (1995). Socio-Economic Life Style of Bangladeshi Man Married to Russian Girl: An Analysis of Migration and Integration Perspective. Russian Management Journal, 6(1), 25-44.

Mannan, K. A., \& Krueger, A. O. (2004). The Impact of Remittances on Household: An Empirical Study on the Bangladeshi Diaspora in United Kingdom. Russian Journal of Economic and Social Science, 12(2), 48-74.

Mannan, K. A., \& Krueger, A. O. (2002). Why do Italy? A Comparative Analysis of Bangladeshi Migrants into Five European Countries. Russian Journal of Economic and Social Science, 10(2), 30-48.

Mannan, K. A., \& Krueger, A. O. (2000). The Dynamics of International Migration: A Three Step Empirical Model of Bangladeshi Migrants in Italy. Russian Journal of Economic and Social Science, 8 (2), 34-58 
Mannan, K. A., \& Krueger, A. O. (1998). Social Capital and Networks Role in Migrants' Labour Market Outcomes at Destination: A Study of Bangladeshi Migrants in Italy. Russian Journal of Economic and Social Science, 6 (2), 5474.

Mannan, K. A., \& Krueger, A. O. (1996). Sustainability of the New Economy: An Empirical Study of Bangladeshi Migrants in Moscow. Russian Journal of Economic and Social Science, 4(2), 65-80.

Mantoo, A. S. (2012). Bangladeshi Illegal Immigration: Effects and Consequences. Journal of Eurasian Studies, 4(3), 38-53.

Masuduzzaman, M. (2014). Workers' remittance inflow, financial development and economic growth: a study on Bangladesh. International Journal Economics and Finance, 6(8), 247-267.

Matin, K. A. (1994). The overseas migrant workers, remittances and the economy of Bangladesh: $1976 / 77$ to 1992/93. Dhaka University Journal of Business Studies, 15(2), 87-109
McKeigue, P. M., Marmot, M. G., Syndercombe-Court, Y. D., Cottier, D. E., Rahman, S., \& Riemersma, R. A. (1988). Diabetes, hyperinsulinaemia and coronary risk factors in Bangladeshis in East London. British Heart Journal, 60, 390396.

Mehdi, S. S. (2010). Illegal migration, human smuggling and trafficking: From Bangladesh to Pakistan and beyond. International Organization for Migration.

Menon, R. (2004). No Woman's Land: Women from Pakistan, India and Bangladesh write on the Partition of India. New Delhi: Women Unlimited

Mohsin, M. (2011). An Investigation of Highly Skilled Bangladeshi Migration to the UK: A Micro Study of Edinburgh and London. Master's thesis, Edinburgh Napier University, Edinburgh, UK.

MPC (Migration Policy Institute). (2014). The Bangladeshi Diaspora in the United States Washington, DC. Available at: https://www.migrationpolicy.o $\mathrm{rg} / \mathrm{sites} /$ default/files/publicatio ns/RAD-Bangladesh.pdf 
Miyan, A M. (2003). Dynamics of labour migration-Bangladesh context, International University of Business Agriculture and Technology. Dhaka.

Moses, J. W. (2009). Leaving poverty behind: A radical proposal for developing Bangladesh through emigration. Development Policy Review, 27(4), 457-479.

Murshid, K. A. S., Iqbal, K., \& Ahmed, M. (2002). A study on remittance inflows and utilization. IOM. Regional Office for South Asia. Dhaka.

Naim, S. T. K. \& Iftikhar, Z. (2008). Migration of highly skilled and its impact on the economic and technological development of Pakistan and Bangladesh. South Asia Network of Economic Research Institutes, 10(11), 2-23.

Nandy, A. K. (2005). Immigration from Bangladesh to India Based on Census Data. Asian and Pacific Migration Journal, 14(4), 487-499.

Naved, R.T., Newby, M., \& Amin, S. (2001). The Effects of Migration on Marriage of Female Garment Workers in Bangladesh. International
Journal of Population Geography, 7 (2), 91-104.

Nasiruddin, A. Z. M. (1983). Policies and Programs Concerning Migration of Labor from Bangladesh to the Middle East. Paper presented at the Conference on Asian Labor Migration to the Middle East, East-West Population Institute, Honolulu, 19-23 September.

Nazneen, R. (2005). Bangladeshi Muslims in Montreal: A case of divided loyalty. International Journal of Sociology of the Family, 31(2), 109-122.

Orozco, M. (2010). Migration, Remittances and Assets in Bangladesh: Considerations about Their Intersection and Development Policy Recommendations. Dhaka: International Organization for Migration, Regional Office for South Asia.

Osmani, S. R. (2016a). .Migration and Remittances in Rural Bangladesh: A Study of Market Failure. London: International Growth Centre.

Osmani, S. R. (2016b). Migration and Remittances in Rural Bangladesh: A Study of Market Failure. Belfast, UK: Ulster University. 
Osmani, S. R. (1991). Migration and Development: The Unsettled Relationship, In Papademetriou and Martin (Ed.), The Unsettled Relationship: Labor Migration and Economic Development. New York: Greenwood Press.

Osmani, S. R. (1986). Bangladesh. In Migration of Asian Workers to the Arab World, edited by Gunatilleke, G. Tokyo: United Nations University.

Osmani, S. R., \& Latif, M. A. (2013). The pattern and determinants of poverty in rural Bangladesh: 2000-2010. Bangladesh Development Studies, 36(2), 140.

Paul, B. P., Uddin, M. G. S., \& Noman, A. M. (2011). Remittances and output in Bangladesh: An ARDL bounds testing approach to cointegration. International Review of Economics, 58(2), 229-242.

Paul, B. P., \& Das, A. (2011). The Remittance-GDP Relationship in the Liberalized Regime of Bangladesh: Cointegration and Innovation Accounting. Theoretical and Applied Economics, 18(9), 41-60.

Peach, C. (1990). Estimating the growth of the Bangladeshi population of Great Britain.
New Community, 16 (4), 48191.

Phillipson, C., Ahmed, N., \& Latimer, J. (2003). Women in Transition: A Study of the Experiences of Bangladeshi Women Living in Tower Hamlets. Policy Press, Bristol.

Pichler, P. (2007). Talking traditions of marriage - Negotiating young British Bangladeshi femininities. Women's Studies International Forum, 30, 201216.

Pollen, R. M. (2002). Bangladeshi life in Bethnal Green. Thesis, University of London.

Pradhan, M. A., \& Khan, G. U. (2015). Role of Remittance for improving quality of life: Evidence from Bangladesh. Turkish Economic Review, 2(3), 160.

Protik, A., \& Kuhn, R. S., (2006). The Hidden Cost of Migration: Effect of Brother's Migration on Sister's Marriage Outcomes in Rural Bangladesh. Brown University.

Qubria, M. G. (1997). International Migration, Remittances and Income Distribution in the Source Country: A Synthesis. Bulletin of Economic Research, 49, 29-46. 
Qubria, M. G. (1989). International migration and real wages: is there any Neoclassical ambiguity? Journal of Development Economics, 31, 177-183.

Quibria M. G. (1986). Migrant Workers and Remittances: Issues for Asian Developing Countries. Asian Development Review, 4.

Quibria, M. G., \& Thant, M. (1988). International labour migration, emigrants' remittances and asian developing countries: economic analysis and policy issues. In M. Dulta (ed.) Research in Asian Economic Studies. Greenwich, Connecticut: Jal Press: 287311.

Rahim, A. (1990). After the Last Journey: Some Reflections on Bangladeshi Community Live in Ontario. PolyPhony, 8-11.

Rahim, N. (2001). A Tarnished Golden Deer: The Regime for Bangladesh Migrant Worker, Programme for Research on Poverty Alleviation Research Report Series, No. 83, Grameen Trust, Dhaka.

Rahman, M. H., Majumder, S. C., \& Hossain, M. N. (2020). The Impact of Exchange Rate Volatility on Export and Import in Bangladesh. European Online Journal of Natural and Social Sciences, 9(2), 411-424.

Rahman, S. (2010). Imagining life under the long shadow of 9/11: Backlash, media discourse, identity and citizenship of the Bangladeshi diaspora in the United States. Cultural Dynamics, 22(1), 49-72.

Rahman, M. M. (2011). Emigration and the Family Economy: Bangladeshi Labour Migration to Saudi Arabia. Asian and Pacific Migration Journal, 20(3-4), 389-411.

Rahman, M. M. (2004a). Migration and poverty in Bangladesh: ironies and paradoxes. In Hisaya Oda (ed.). International Labor Migration from South Asia, Institute of Developing Economies, JETRO, Japan, ASEDP 70, 181-208.

Rahman, M. M. (2004b). Migration networks: an analysis of Bangladeshi migration to Singapore. Asian Profile, 32(4), 367-390.

Rahman, M. M. (2000). Emigration and Development: The Case of a Bangladeshi Village', International Migration, 38(4).

Rahman, M. M. (1999). The Impact of Asian Economic Crisis on 
Migrant Workers: The Case of Bangladeshi Workers in Singapore. Working Paper, 147, Department of Sociology, National University of Singapore.

Rahman, M. M., \& Yeoh, B. S. A. (2008). The social organization of Hundi: the remittance transfer from East and Southeast Asia to Bangladesh. Asian Population Studies, 4(1), 5-29.

Rahman, M., \& Rahman, M. (2008). Impact of migration on Bangladesh economy: A critical analysis. Europe, 727(56.1), 7.7.

Rahman, M. (2009). Contribution of Exports, FDI, and Expatriates' Remittances to Real GDP of Bangladesh, India, Pakistan and Sri Lanka. Southwestern Economic Review, 36, 141153.

Rahman, M., Mustafa, M., Islan, A., \& Guru-Gharana, K. K. (2006). Growth and Employment Empirics of Bangladesh. Journal of Developing Areas, 40(1), 99-114.

Rahim, A. B. M. (2002). Future of labour export to Saudi Arabia. In Siddiqui Tasneem. (ed) op.cit. 104-107.
Raihan, S., Khondker, B. H., Sugiyarto, G., \& Jha, S. (2009). Remittances and household welfare: a case study of Bangladesh. Manila: Asian Development Bank, ADB working paper. No. 189.

Ramachandran, S. (2005). Indifference, impotence, and intolerance: transnational Bangladeshis in India. Global Migration Perspectives. No. 42. Geneva.

Rao, B. B., \& Hassan, G. M. (2012). Are the direct and indirect growth effects of remittances significant?. The World Economy, 35(3), 351-372.

Rasinger, S. M. (2013). Language shift and vitality perceptions amongst London's second generation Bangladeshis. Journal of Multilingual and Multicultural Development, 34(1), 46-60.

Rashid, S. R. (2016). Gendered practices of remittances in Bangladesh: A postculturist perspective. Working Paper 42, Migrating out of Poverty, University of Sussex.

Rashid S. R. (2002). Vulnerability of cross border labour migrants to HIV/AIDS, commissioned by HIV/AIDS and STD Alliance 
Bangladesh

(HASAB).

RMMRU. Dhaka.

Regmi, M., \& Paudel, K. P. (2016). Impact of remittance on food security in Bangladesh. Frontiers of Economics and Globalization, 16, 145-158.

Reza, S. (2002). Labour Situation in Kuwait. In Tasneem Siddiqui [ed] Beyond the maze: streaming labour recruitment process in Bangladesh. RMMRU, 120-126. Dhaka.

Roshid, M. M., \& Chowdhury, R. (2013). English language proficiency and employment: A case study of Bangladeshi graduates in Australian employment market. Mevlana International Journal of Education (MIJE), 3(1), 68-81.

Rozario, S. (2007). Outside the moral economy? Single female migrants and the changing Bangladeshi family. The Australian Journal of Anthropology, 18(2), 154-171.

Rudinick, A. (1995). Foreign Labor in Malaysian Manufacturing: Bangladeshi workers in the Textile Industry, INSAN, Kuala Lumpur.

Salim, R. A. (1992). Overseas remittances in Bangladesh: Importance, potentialities and policy options. Jahangirnagar Review, Part II, Social Science XIII \& XIV, Jahangirnagar University, Dhaka

Salway, S. (2007). Economic Activity among UK Bangladeshi and Pakistani Women in the 1990s: Evidence for Continuity or Change in the Family Resources Survey. Journal of Ethnic and Migration Studies, 33(5), 825-847.

Samson, N. (2007). Speaking of home: Bangladeshi women In London's East End reflect on belonging dissertation, University of East London.

Sarkar, M. S. K., Rahman, M. Z., Islam, M. M., Sikdar, M. M. H., \& Khan, A. B. (2018). Relationship between Remittance and Economic Growth: Evidence from Bangladesh. American Journal of Trade and Policy, 5(1), 1520.

Sarker, M., \& Islam, M. S. (2014). Husbands' international labour migration and the change of wives' position among the leftbehind in rural Bangladesh. Research on Humanities and Social Science, 4(16), 57-62.

Sarma, M. (2015). A study of migration from Bangladesh to Assam, India and its impact. 
Doctoral thesis, The University of Adelaide, Australia.

Sarmah, K., \& Protim, D. U. (2014). Illegal Migration into Assam from Bangladesh: Causes and Consequences. Galaxy: International Multidisciplinary Research Journal.

Sayan, S. (2006). Business Cycles and Workers' Remittances: How Do Migrant Workers Respond to Cyclical Movements of GDP at Home? IMF Working Paper: WP/06/52.

Sharma, M., \& Zaman, H. (2009). Who migrates overseas and is it worth their while? An assessment of household survey data from Bangladesh. Policy Research Working Paper Series 5018, The World Bank, Washington DC.

Shamshad, R. (2008). Politics and Origin of the India-Bangladesh Border Fence. Paper presented on $17^{\text {th }}$ Biennial Conference of the Asian Studies Association of Australia in Melbourne, July.

Shamim, I. (2000). Trafficking in Women and Children: A Human Rights Concern. In CR Abrar [ed] On the Margin: Refugees, Migrants and Minorities. RMMRU, Dhaka.
Shafiq, S.B. (2016). Settlement Experiences of Bangladeshi Migrants in Australia. (Doctoral dissertation, Swinburne University of Technology, Australia).

Siddiqui, A.M.A.H. (1983). Rural Vocational Training Needs: A Case Study of Bangladesh. Dhaka: Bangladesh Manpower Planning Center, Ministry of Labor and Manpower.

Siddiqui, T. (2017). Untold Stories of Migrants: Dreams and Realities. Dhaka: Refugee and Migratory Movements Research Unit.

Siddiqui, T. (2016). International Labour Migration and Remittances. in Riaz Rahman, S.M. (Eds.) Routledge Handbook of Contemporary Bangladesh, New York: Routledge.

Siddiqui, T. (2005). International labour migration from Bangladesh: A decent work perspective. Policy Integration Department Working Paper, Working Paper No 66, International Labour Office, Geneva.

Siddiqui, T. (2004a). Institutionalizing diaspora linkage: The emigrant Bangladeshis in UK and USA. 
Dhaka: International Organization for Migration.

Siddiqui, T. (2004b). Efficiency of migrant workers' remittance: the Bangladesh case. Asian Development Bank, Manila.

Siddiqui, T. (2003a). Migration as a livelihood strategy of the poor: the Bangladesh case. Refugee and Migratory Movements Research Unit, Dhaka University

Siddiqui, T. (2003b). Institutionalising Re-bonding: Bangladeshi Diaspora in UK and US. Dhaka, Ministry of Expatriates' Welfare and Overseas Employment of Govt. of Bangladesh and IOM.

Siddiqui, T. (2003c). Migration as livelihood option of the Poor. The DFID/RMMRU conference on Migration, Development and Pro-Poor Policy Choices. Dhaka.

Siddiqui, T. (2001). Transcending Boundaries: Labour Migration of Women from Bangladesh. Dhaka, UPL.

Siddiqui, T., \& Abrar, C. R. (2001a). Migrant worker remittances and micro-finance in Bangladesh. Social finance programme. Working paper
No. 38. RMMRU and International Labour Office.

Siddiqui, T., \& Abrar, C. R. (2001b). Migrant Workers' Remittances and Micro-finance Institutions. ILO.

Siddiqui, T., \& Abrar, C. R. (2000). Contribution of Returnees: An Analytical Survey of Postreturn Experience. IOM/UNDP.

Siddiqui, T., Malik S., \& Abrar C. R. (1999). Labour Migration from Bangladesh and the Trade Unions. ILO.

Sikder, M. J. U. (2008). Bangladesh. In Asian and Pacific Migration Journal, 17 (3-4), 257-275.

Stahl, C. W., \& Habib. A. (1989). The Impact of Workers' Remittances on Indigenous Industries: Evidence from Bangladesh. The Developing Economies, 27 (3), 269-285.

Stevanovic, N. (2012). Remittances and moral economies of Bangladeshi New York immigrants in light of the economic crisis. Doctoral Dissertation, Columbia University: New York.

Subhan, S. (2007). Heritage language maintenance among Bangladeshi immigrants in Toronto. Doctoral dissertation, 
Northern Arizona University, Flagstaff, Arizona, United States.

Sultana, N. (2008). The Bangladeshi Diaspora in Malaysia. $\mathrm{PhD}$ thesis, University of Bonn, Germany.

Sultana, M. (2005). Do Migrants Transfer Tacit Knowledge? The Case of Highly Skilled Bangladeshi Immigrants in the United States. Master's thesis, Massachusetts Institute of Technology, Cambridge, MA.

Sultana, N., \& Brahmmanbaria, B. (2008). Bangladeshi Diaspora in Peninsular Malaysia Organizational Structure, Survival Strategies and Networks. Universitäts-und Landesbibliothek Bonn.

Summerfield, H. (1993). Patterns of adaptation: Somali and Bangladeshi women in Britain. In Migrant women: crossing boundaries and changing identities(ed) G. Buijs. Oxford: Berg.

Tackey, N. D., Casebourne, J., Aston, J., Ritchie, H., Sinclair, A., Tyers, C., Hurstfield, J., \& Willison, R., (2006). Barriers to employment for Pakistanis and Bangladeshis in Britain. Department for Work and
Pensions. Page, Research Report DWPRR 360. August.

Taguchi, H., \& Lama, B. (2016). Do Emigrant's Remittances Cause "Dutch Disease"?: The Case of Nepal and Bangladesh. Research in Applied Economics, 8(4), 1-15.

Tahmina, Q. A. (2003). Weak bargaining power heightens risks for women migrants. 8th Regional Conference on Migration in Dhaka, Bangladesh in October organized by the Migrant Forum in Asia (MFA). Asian Migrant Centre and the Welfare Association for Repatriated Bangladeshi Employees (WARBE).

Titumir, R. A. M. (2002). Migrant workers of Bangladesh and their vulnerability to HIV/AIDS: The Post-return phase. HASAB. RMMRU. Dhaka.

Tomlinson, S. (1992). Disadvantaging the Disadvantaged: Bangladeshis and Education in Tower Hamlets. British Journal of Sociology of Education 13 (4), 437-446.

Ullah, A. K. M. A., \& Panday, P. K. (2006). Remitting money to Bangladesh: what do migrants prefer?. Asian and Pacific 
Migration Journal, 16(1), 12137.

Wadood, S. N., \& Hossain, A. (2017). Microeconomic impact of remittances on household welfare: Evidence from Bangladesh. Business and Economic Horizons (BEH), 13(1), 10-29.

Ward, J., \& Spacey, R. (2008). Dare to Dream: Learning journey of Bangladeshi, Pakistani and Somali women. National Institute of Adult Continuing Education, England and Wales

White, S. (1994) Purdah, Female Power and Cultural Change: A Sylheti Example. The Journal of Social Studies, 65, 1-24.

White, S. (1992). Arguing with the Crocodile: Class and Gender in Bangladesh, London: Zed Press.

Zamir, Z. B. (2006). Migrant Workerse Contribution in Malaysian Economy. Bangladesh: Cosmic Publishers.

Zahid, B. Z. (1998). Socio- Economic Conditions of Migrant Workers: A case study of Bangladeshi Workers in Selangor Malaysia. Masters Thesis, International Islamic University [mimeo].
Zeitlyn, B. (2006). Migration from Bangladesh to Italy and Spain. RMMRU. Dhaka. 